Sains Malaysiana 48(8)(2019): 1685-1695

http://dx.doi.org/10.17576/jsm-2019-4808-14

\title{
Genotoxicity and Cytotoxicity of Orthodontic Bonding Adhesives: A Review
}

(Kegenotoksikan dan Kesitotoksikan Pelekat Ikatan Ortodontik: Suatu Kajian)

\author{
Riaz MOHAMmad ADHAm, NORMA Ab RAHMAN* \& THIRUMUlu PONNURAJ KANNAN
}

\begin{abstract}
Orthodontic bonding adhesive is one of the integral parts of orthodontic treatment. By means of orthodontic bonding adhesives, different components of fixed orthodontic appliances are attached to the tooth surface. Manufacturers have been introducing various bonding adhesives as there is an increasing demand for orthodontic treatment presently. Focus has been made more on the physical properties of these bonding adhesives rather than their biocompatibility. As orthodontic treatment is a long-time process, the bonding adhesives also remain in close proximity with intra-oral tissues. Therefore, biocompatibility of these adhesives in respect to their genotoxicity and cytotoxicity should be a concern while clinically implicating them. The aim of this review was to provide information about the genotoxicity and cytotoxicity effects of various orthodontic bonding adhesives. An electronic search was conducted across Cochrane, Medline, Web of Science databases, and Google Scholar for literature analysis on the mentioned topic. The studies were reviewed and compared. This article summarizes the results of research studies that have been done to see the genotoxicity and cytotoxicity of orthodontic bonding adhesives. Most research studies summarized in this review article concluded that orthodontic bonding adhesives show some extent of either genotoxicity or cytotoxicity or both. There is still a lack of scientific literature on long-term in vivo studies on the toxic effects of these adhesives. It is advisable to employ several genetic assays and standardized methods for genotoxic evaluation of bonding adhesives through longtime clinical in vivo studies.
\end{abstract}

Keywords: Adhesives; bonding; cytotoxicity; genotoxicity; orthodontic

\section{ABSTRAK}

Pelekat ikatan ortodontik adalah salah sebahagian daripada rawatan ortodontik. Menggunakan sistem ikatan ortodontik ini, komponen peralatan ortodontik dapat melekat pada permukaan gigi. Pengilang telah memperkenalkan pelbagai jenis pelekat ikatan ortodontik kerana terdapat peningkatan permintaan untuk rawatan ortodontik pada masa ini yang memfokuskan pada sifat fizikal pelekatan ikatan ini. Oleh kerana rawatan ortodontik adalah proses jangka panjang, pelekat ikatan ortodontik mungkin mempunyai hubungan dengan tisu intra-oral mulut. Oleh itu, bioserasi pelekat, dengan tumpuan kepada kegenotoksikan dan kesitotoksikan telah menjadi perhatian apabila diuji secara klinikal. Tujuan kajian ini adalah untuk memberikan maklumat tentang kesan kegenotoksikan dan kesitotoksikan daripada pelbagai jenis pelekat ikatan ortodontik. Carian elektronik dijalankan melalui pangkalan data Cochrane, Medline, Web of Science, dan Google Scholar untuk analisis kepada topik yang disebutkan. Kertas ini merumuskan hasil kajian penyelidikan yang telah dilakukan untuk melihat kesan kegenotoksikan dan kesitotoksikan pelekat ikatan ortodontik. Kebanyakan kajian penyelidikan yang menyimpulkan bahawa pelekat ikatan ortodontik menunjukkan beberapa tahap kegenotoksikan atau kesitotoksikan atau kedua-duanya. Masih kurang keputusan saintifik mengenai kajian in vivo jangka panjang mengenai kesan toksik pelekat ikatan ortodontik ini. Dengan itu adalah disarankan untuk menggunakan beberapa jenis ujian genetik untuk membuat penilaian genotoksik pelekat ikatan ortodontik untuk kajian in vivo klinikal jangka panjang.

Kata kunci: Ikatan; kegenotoksikan; kesitotoksikan; ortodontik; pelekat

\section{INTRODUCTION}

One of the significant advancements of modern orthodontics is direct bonding. Bonded brackets have replaced cemented bands with the development of reliable and reproducible bonding technique. Manufacturers have introduced different types of bonding adhesives as there is increased use of directly bonding orthodontic appliances. Primary focus of development and subsequent marketing of these bonding materials have been on their physical properties, including ease of handling and bond strength (Bishara et al. 1998; Rix et al. 2001; Rueggeberg et al. 1992; Wright et al. 1996). Clinically, there are several types of orthodontic adhesives used for the attachment of orthodontic appliances; these include self-cure bonding resin, lightcure bonding resin, and hybrid glass ionomer cement (GIC). Self-cure bonding adhesives are also known as chemical cured adhesives as the adhesives itself set when different components of the adhesives system are mixed. Light-cure bonding adhesives are the composite adhesives that needs light activation for curing. Major advantage of light cure 
bonding adhesives is the increased working time. Hybrid GIC is the type of GIC in which the liquid components are modified in such that they cure when photo initiators are applied. This type of adhesives is more aesthetic than other types. Biocompatibility is of primary importance when it comes for the selection of dental materials, as contact or interaction with oral tissues and body fluids may cause local and or systemic adverse effects. Several studies have reported biological and toxic effects by dental adhesives (Hanks et al. 1992, 1991).

Biocompatibility is the ability of some material to perform with an appropriate host response when applied to biological tissues (Angelieri et al. 2018). To date, there are many experimental models available to evaluate the biocompatibility of materials used in dental and medical practices using different methodologies and end-points so far. Genotoxicity and cytotoxicity tests are particularly relevant biologically as they are closely related to the initiation phase of carcinogenesis, due to cell cycle proliferation stimulus, or an error of mitotic phase secondary to cell deoxyribonucleic acid (DNA) damage with subsequent repair capacity impaired (Bull et al. 2006). Hence, it is important to investigate if the bonding adhesives used in orthodontics induce genetic damage and cellular death in mammalian cells. The current review provides an overview of the literature available on cytotoxicity and genotoxicity of orthodontic adhesives.

\section{MATERIALS AND METHODS}

An electronic search was conducted across Cochrane, Medline, Web of Science databases, and Google Scholar for literature analysis on the mentioned topic. The studies were reviewed and compared. This article summarizes the results of research studies that have been done to see the genotoxicity and cytotoxicity of orthodontic bonding adhesives.

\section{DISCUSSION}

\section{GENOTOXICITY OF ORTHODONTIC ADHESIVES}

The genotoxic properties of orthodontic adhesives are essential for determining the biological safety of these materials in patients. Genotoxicity tests can be defined as in vitro and in vivo approaches designed to detect compounds that induce genetic damage, including DNA lesions, gene mutation, chromosomal breakage, altered DNA repair capacity, and cellular transformation (Angelieri et al. 2011b, 2011a). It has to be noted also that no single genotoxicity test can detect all relevant genotoxic agents. Therefore, in accordance with current regulatory requirements, medical devices are assessed for genotoxic potential with a battery of in vitro and in vivo genotoxicity assays. According to the International Standard ISO-109933 , (1998), the following battery of tests is proposed to test genotoxicity: A test for gene mutation in bacteria (Ames test)(OECD 471, 1997) which is conducted with strains of
Salmonella typhimurium and Escherichia coli designed to detect all possible single base pair changes as well as frameshift mutations; an in vitro mammalian genotoxicity assay, such as one of the following recommended tests: the Mouse Lymphoma gene mutation assay (MLA) (OECD 476, 1997), which is preferred because it detects the broadest set of genotoxic mechanisms associated with carcinogenic activity, an in vitro chromosomal aberration (CA) assay (OECD 473, 2016), or an in vitro micronucleus (MN) assay (OECD 487, 2016); and an in vivo cytogenetics assay, such as one of the following recommended tests: a bone marrow MN assay (OECD 474, 2016), a bone marrow CA assay (OECD 475,2016 ), or a peripheral blood MN assay.

The different genotoxic assays available in the scientific literature on orthodontic bonding adhesives are presented in Table 1. The data from related research suggest that studies on the genotoxicity and DNA damage resulting from orthodontic materials are rare. Some of the assays mentioned have been utilized in research studies, such as the Salmonella reverse-mutation test (Cross et al. 1983; Fredericks 1981), MN assay (Toy et al.2014) and alkaline version of comet assay (Angelieri et al. 2018; Ravi et al. 2013).

In two studies in the early ' 80 s, the researchers investigated the mutagenicity of different types of orthodontic adhesives using Ames test (Cross et al. 1983; Fredericks 1981). Both used the 'spot test' version of Ames test as an initial screening method. The spot test is useful mainly as a qualitative test; therefore, the specific number of colonies per plate is of minimal importance. To evaluate the results of the spot test, the growth of colonies was scored as negative, weakly positive, or positive. The test was considered negative if there was no ring of growth around the sample. Fredericks investigated Adaptic (Johnson \& Johnson), Concise (3M), Dynabond (Unitek), Endur (Ormco), Interlok (Rocky Mountain), Lee Unique (Lee Pharmaceuticals), Nuva Seal (Caulk Company) and System I (Ormco) (Fredericks 1981). Only the liquid component from each adhesive was screened initially by 'spot test' using the bacterial strains TA 98, TA 100 and TA 1535 of Salmonella typhimurium. Each liquid component was examined in eight determinations; three using TA100, three using TA98 and two using TA1535. Lee Unique primer gave a positive result in three determinations of TA 100 which were then evaluated further using dose-response curve where two batches of Lee unique primer were used. The result in the dose-response test characterized Lee Unique primer as 'weakly positive' due to the technical difficulties in obtaining homogenous concentration on top agar of materials and high variability. All liquid components were tested in this study prior to their polymerization; therefore, it was unknown to which extent the residual mutagenicity can occur post-polymerization. In 1983, Cross et al. investigated Super-C Ortho ('A' Company, San Diego, Calif), System I Orthodontic Bonding (American Ormco, Glendora, Calif), 1-step Orthodontic bonding Adhesives (Beta Dental Inc, San Diego, Calif), Lee Insta-Bond (Lee Pharmaceuticals, El Monte, Calif), Mono-Lok Bonding 


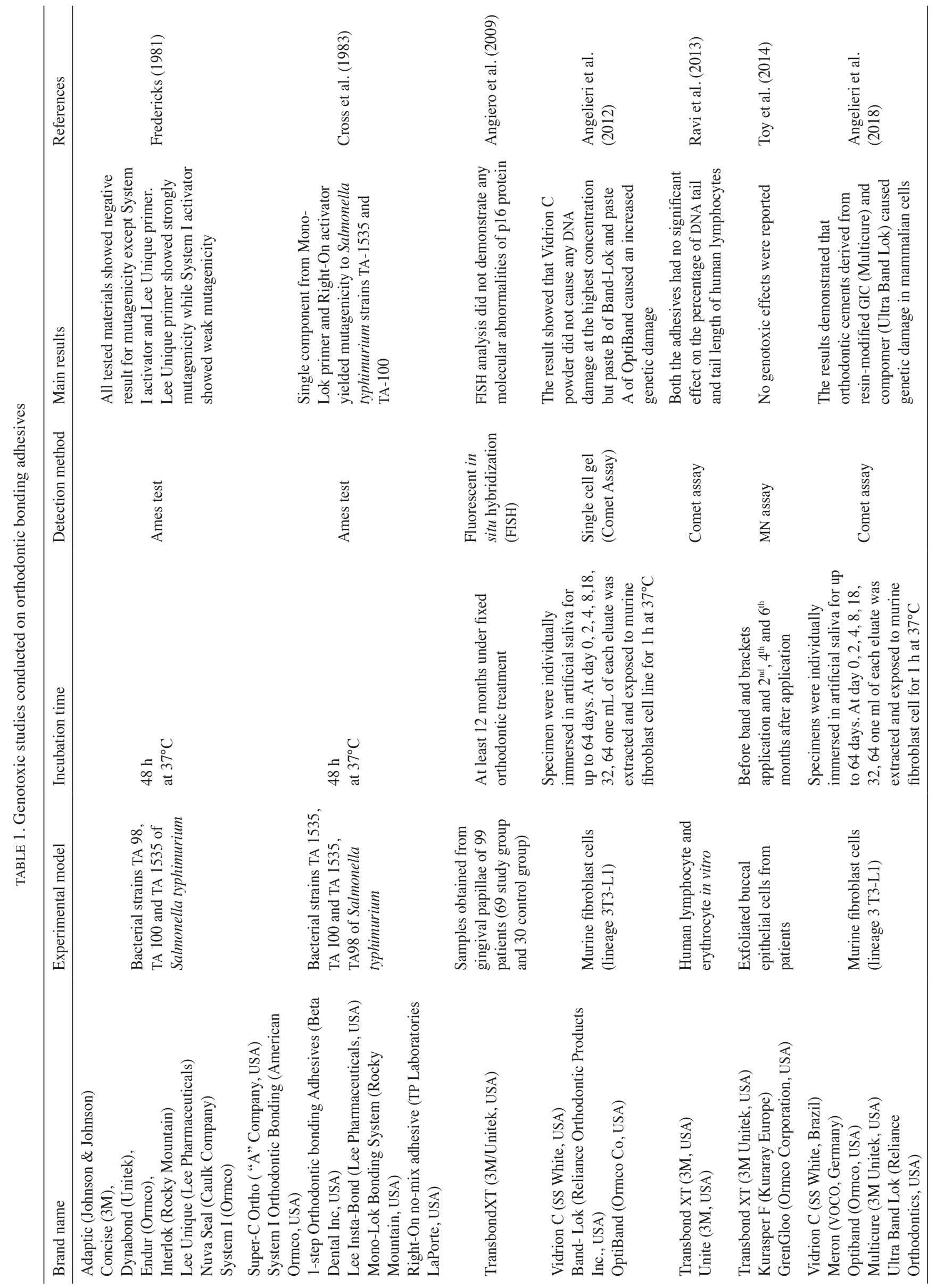


System (Rocky Mountain, Denver, Colo), Right-On nomix adhesive (TP Laboratories LaPorte, Ind) for their mutagenicity using 'spot test' version of Ames test using. The research group used TA 100, TA 98, TA1538 and TA 1535 tester strains of Salmonella typhimurium. Mono-Lok primer and Right-On activator gave a positive response in 'spot test' for the tester strain TA-100. Later, these two components were investigated after polymerization by an independent laboratory for a dose-response effect which concluded that they were mutagenic in the Ames test with the strain TA- 100 .

The MN assay has been used to evaluate the genotoxicity of dental adhesives (Angelieri et al. 2011a). MN deposits contain abnormal genetic material that was lost from the genome during mitosis because of toxic exposure of cells to radiation or chemical agents. The MN assay is a validated alternative way of sensitive detection for CA (Stick \& Rosin 1983). Some genotoxic chemicals, for example, tobacco products, pesticides, and alcohol have been examined in exfoliated buccal mucosa cells using estimates of MN formation (Schweikl et al. 2001). In 2014, Toy et al. evaluated the genotoxicity of three light-cured orthodontic bonding composites by analyzing MN formation in the buccal mucosal cells during a six month period using MN assay. Transbond XT (3M Unitek), Kurasper F (Kuraray Europe), and GrenGloo (Ormco Corporation) were used in this study. The authors concluded that after six months, the MN rates did not have any significant differences.

The single-cell gel (comet) assay in the alkaline version was designed as a rapid, simple and reliable biochemical technique for evaluating DNA strand breaks in mammalian cells (McKelvey-Martin et al. 1993). Some advantages of the comet assay have been elected when compared to other genotoxicity assays because it is cheap and has reproducible results (Brendler-Schwaab et al. 2005). The basic principle of the comet assay resides on the migration of DNA fragments because of double-strand breaks, single strand breaks, adducts and incomplete repair sites through agarose matrix under electrophoresis conditions. Nucleoids look like comets with a head (the nuclear region) and a tail containing DNA fragments by conventional light microscopy (Tice et al. 2000).

In 2012, Angelieri et al. used comet assay to evaluate the genotoxicity of three different types of GIC used in orthodontics (Vidrion C, OptiBand and Band-Lok). All tested cement components were exposed to murine fibroblast cells in-vitro for $1 \mathrm{~h}$ at $37^{\circ} \mathrm{C}$ to see the DNA damage. The result showed that Vidrion $\mathrm{C}$ powder did not cause any DNA damage at the highest concentration but paste B of Band-Lok and paste A of OptiBand caused increased genetic damage. In 2018, the same research group conducted another study to evaluate genotoxic effects of five commercially available GIC (Vidrion C, Meron, Optiband, Multicure and Ultra Band Lok) using comet assay at different time intervals $(0,2,4,8,18,32$ and 64 days of immersion in artificial saliva at $37^{\circ} \mathrm{C}$ ) in murine fibroblast cells (Angelieri et al. 2018). The majority of orthodontic cements tested in the study did cause genetic damage in the highest concentration used, while Meron, showed early genotoxicity in this setting ( 2 day-eluate of exposure). Ultrabandlok was able to induce genotoxicity after 18, 32 and 64 days of exposure, whereas, Multircure induced genotoxicity after 32 and 64 days of exposure. Taken together, the results demonstrated that orthodontic cements derived from resin-modified GIC (Multicure) and compomer (Ultra Band Lok) cause genetic damage in mammalian cells in vitro. Since in vitro studies do not take into account the complex homeostatic scenario that occurs in vivo, complementary experimental models and clinical studies are required for better understanding of the biological behaviour of orthodontic cements on mammalian cells.

Therefore, Angelieri et al. (2018) assumed that genotoxicity of murine fibroblasts induced by eluates was in a dose-dependent fashion. This occurred characteristically for resin-modified and compomer GIC. Such findings are important to understand better that some orthodontic cements from resin-modified and compomers can release some compounds that in turn cause genetic damage in mammalian cells. It has been demonstrated that some compounds are released from GIC too (Forss 1993; Müller et al. 2003). 2-hydroxyethyl methacrylate (HEMA) is a known genotoxic agent found both in resin-modified GIC and compomers. Studies have been conducted where UMUtest was performed in vitro to evaluate the biocompatibility of HEMA containing resin-modified GIC (Falconi et al. 2007; Müller et al. 2003). The authors have suggested that HEMA can induce genetic damage at concentrations from $27 \mathrm{mM}$ to $66.7 \mathrm{mM}$. The powder of Vitrebond (resin-modified GIC) induced genetic damage. The authors concluded that genotoxicity should not be attributed to this compound solely. However, Ribeiro et al. (2006a) did not report in vitro genotoxicity to mouse lymphoma cells exposed to the powder of Vitrebond at concentrations ranging from $1 \mu \mathrm{g} / \mathrm{mL}^{-1}$ to $100 \mu \mathrm{g} / \mathrm{mL}^{-1}$ by comet assay. On the other hand, they demonstrated that the liquid from Vitrebond was genotoxic in a final volume of $0.1 \%$ (Ribeiro et al. 2006a). Therefore, both studies concluded that powders and liquids from GIC caused genetic damage in mammalian cells in a dose-dependent manner.

Comet assay was used in another study in 2013 by Ravi et al. to evaluate in vitro genotoxicity of light cure orthodontic adhesives (Transbond XT, 3M) and self-cure orthodontic adhesive (Unite, $3 \mathrm{M}$ ) on human lymphocytes. Cured sterile individual masses were immersed in DMEM and left at $37^{\circ} \mathrm{C}$ for $24 \mathrm{~h}$. Then, a volume of $200 \mu \mathrm{L}$ of the extract medium was mixed with human peripheral blood lymphocyte for performing comet assay. The result showed that there was a significant increase in the tail length and percentage of DNA tail in Transbond light cure compared with normal lymphocytes and self-cure orthodontic adhesive.

Composite resins contain Triethylene glycol dimethacrylate (TEGMA), Urethane dimethacrylate (UDMA) and Bisphenol-Glycidyl Methacrylate (BisGMA) in their 
composition, which was able to induce DNA injury in several concentrations (Ribeiro et al. 2006b). It is important to stress that genotoxicity is intimately related to the multistep carcinogenesis process since the injured cells remain in the proliferative cycle rather than undergoing apoptosis (exclusion from the proliferative cycle).

\section{CYTOTOXIC EFFECTS OF ORTHODONTIC ADHESIVES}

In vitro cytotoxicity tests constitute an efficient first step in a biocompatibility study and reduce animal use in the laboratory (Assad et al. 1994). The term 'cytotoxicity' is used to describe the cascade of molecular events that interfere with macromolecular synthesis and lead to unequivocal cellular, functional and structural damage (Aldridge 1993; Murray et al. 2007). Regarding dental treatments, it is advantageous to maintain maximal tissue vitality and cytotoxic reactions must be prevented, which necessitates the dental compounds to be screened before they are used clinically (Murray et al. 2007).

The recommended testing methods use cell counting, dye-binding, metabolic impairment or membrane integrity as end-points for the cytotoxicity test or assay (Murray et al. 2007). Among them, the MTT test is the most popular (Ahrari et al. 2010; Heravi et al. 2013; Huang et al. 2002; Jagdish et al. 2009; Malkoc et al. 2010; Saito et al. 2009; Tang et al. 1999). This assay is based on the capacity of the cells to reduce the tetrazolium dye MTT 3-(4,5-methylthiazol-2-yr)-2,5-diphenyltetrazolium bromide to insoluble formazan through the activity of the mitochondrial succinate dehydrogenase in living cells. Assays based on cell staining (with neutral red or trypan blue) are also frequently used (Angelieri et al. 2012; Angelieri et al. 2018). Other assays like lactate dehydrogenase (LDH) assay (Vande Vannet \& Hanssens 2007), hemolysis assay, apoptosis assay (Ravi et al. 2013), real-time xCELLigence system assay (Ozturk et al. 2014) have also been used. The available reports in the literature are shown in Table 2.

The experimental models used to evaluate the cytotoxicity of orthodontic bonding adhesives mainly include established cell lines of human and non-human origins. Regarding human cell lines, cell types found within the area of orthodontic bonding application such as human oral fibroblasts (HOFs) (Ahrari et al. 2010; Heravi et al. 2013; Huang et al. 2002; Ozturk et al. 2014; Saito et al. 2009; Tang et al. 1999), reconstituted human oral epithelium (Vande Vannet \& Hanssens 2007), human oral squamous cell (Huang et al. 2002) and cells not related to orthodontic treatments such as human lymphocytes and erythrocytes (Ravi et al. 2013). Cell lines of non-human origins that were used were Vero cells (Jagdish et al. 2009; Terhune et al. 1983), L929 mouse fibroblast cells (Jonke et al. 2008; Malkoc et al. 2010) and murine fibroblast cells (lineage 3T3-L1) (Angelieri et al. 2018, 2012).

In two studies, a different approach was used to evaluate the cytotoxicity of orthodontic adhesives by taking cells directly from patients undergoing orthodontic treatment. In 2009, Angiero et al. obtained their samples from patients who had been undergoing fixed orthodontic treatment (where Transbond XT, 3M Unitek were used as orthodontic adhesives) for at least 12 months by surgically removing gingival papillae. They looked at the microscopic morphological changes in cells to evaluate the cytotoxicity of the adhesives and found no morphological change indicative of cytotoxicity in any of the cases. Toy et al. (2014), scraped buccal epithelial cells from 30 patients undergoing orthodontic treatment to evaluate cytotoxicity of three different adhesives- Transbond XT(3M Unitek Ortho Prod, Monroe, LA, USA), Kurasper F (Kuraray Europe GmbH, Frankfurt, Germany) and GrenGloo (Ormco Corporation, Orange, CA, USA). Samples were collected every two months' time interval up to six months. They assessed the nuclear alteration in the form of karyorrhexis (KR), karyolysis (KL), and binucleated cells (BNs) to determine the cytotoxicity. The result showed that the number of BNs in buccal epithelial cells significantly increased in all adhesives group, frequency of KL significantly increased in all groups except for Transbond XT and no significant change was observed in frequency of KR among all groups at any time point. Such results may be due to the effect of adhesive composition and the metallic appliances properties, either individually or in combination. Differences in the frequency of $\mathrm{KL}$ between second and sixth month and between fourth and sixth month were only significant in the GreenGloo group. Authors hypothesized that due to the presence of uncured methacrylate ester monomers, GreenGloo may have a slightly greater cytotoxic effect than the other adhesives. Unreacted methacrylate monomers, such as HEMA, UDMA, and Bis-GMA, are dissolved in the lipid bilayers of cell membranes. Since these hydrophobic monomers are often associated with HEMA, it increases the hydrophilic properties of the compound and these monomers can diffuse easily in the cell. Under existing circumstances, the hydrophobic monomers can attach and cause damage to the cells (Santos et al. 2010).

Transbond XT (3M Unitek) was the mostly used material in studies as shown in Table 2 (Ahrari et al. 2010; Angiero et al. 2009; Heravi et al. 2013; Huang et al. 2002; Jagdish et al. 2009; Jonke et al. 2008; Malkoc et al. 2010; Ozturk et al. 2014; Ravi et al. 2013; Tang et al. 1999; Vande Vannet \& Hanssens 2007). There are some differences in the result regarding the cytotoxicity of Transbond XT in different studies. Two research groups found it to be noncytotoxic (Ahrari et al. 2010; Angiero et al. 2009) and one group mentioned it as less cytotoxic compared to the dual cured orthodontic adhesives (Jagdish et al. 2009). Vannet et al. (2007), topically exposed primer of Transbond XT to RHOE which were then fixed, cut and stained for light microscopy (LM) and transmission electron microscopy (TEM). Cytotoxicity detection was then performed by measuring LDH activity. According to the study result, the research group concluded Transbond XT as an acute cytotoxic agent (Vande Vannet \& Hanssens 2007). Toy et al. (2014) also mentioned that Transbond XT exhibited 


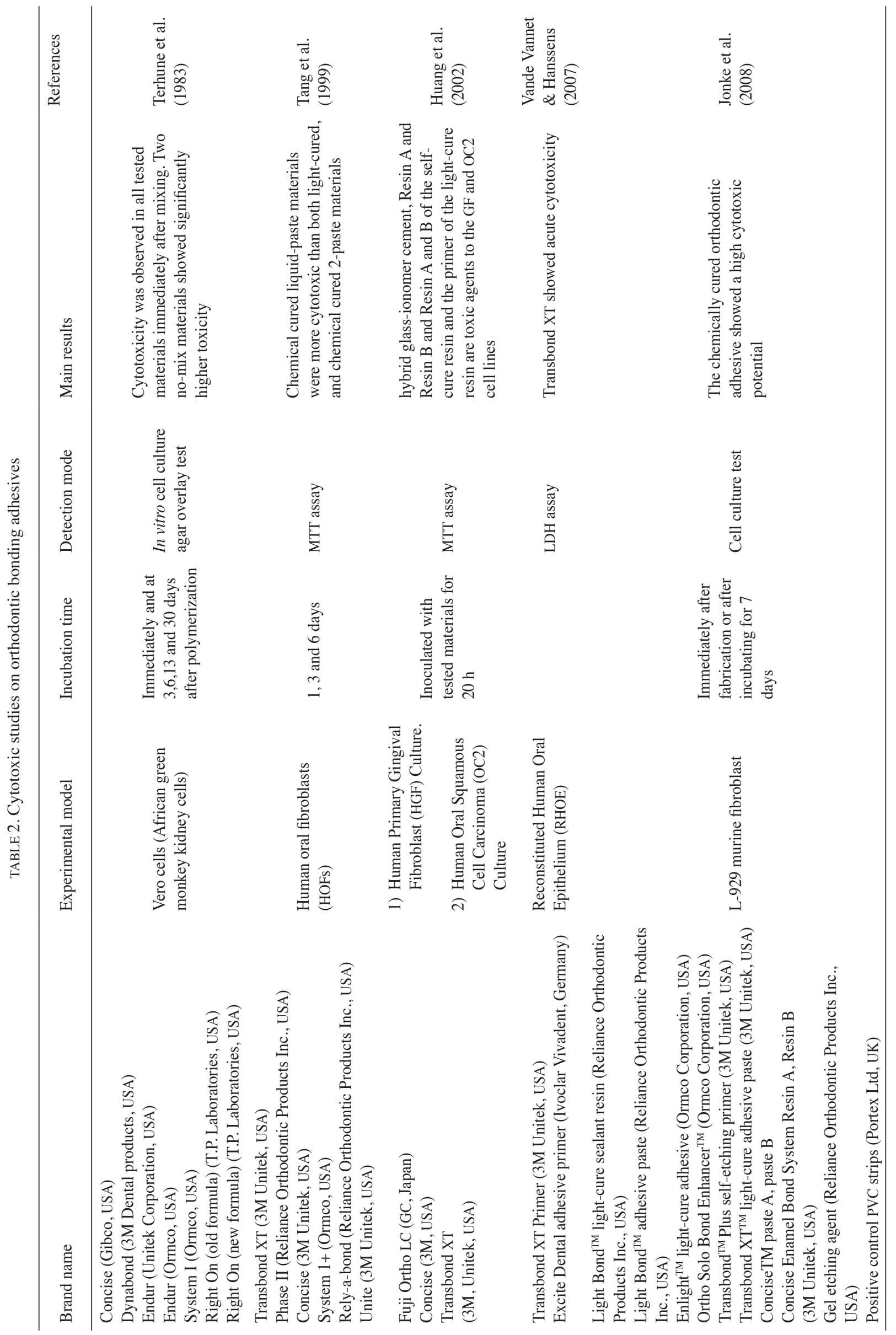




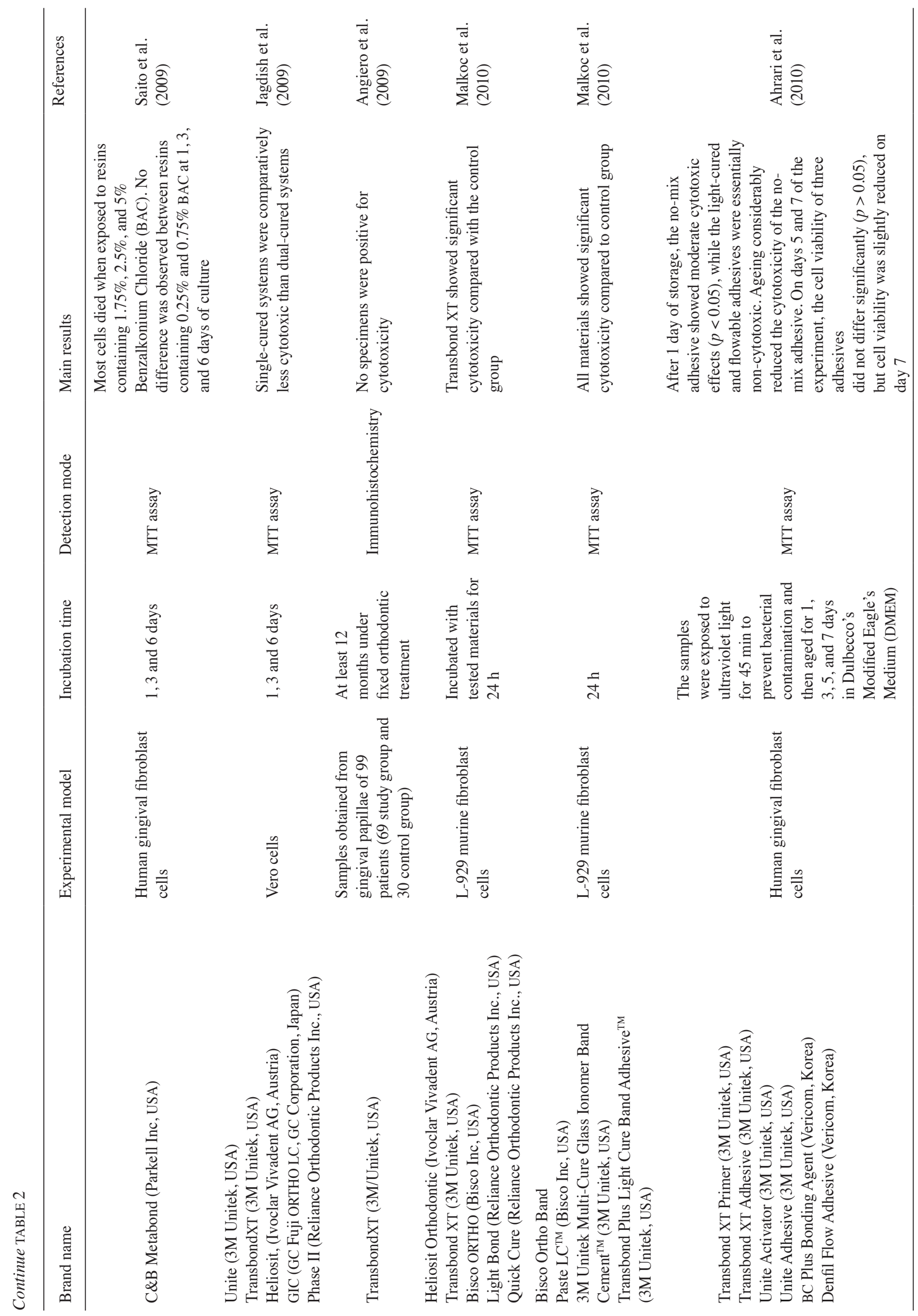




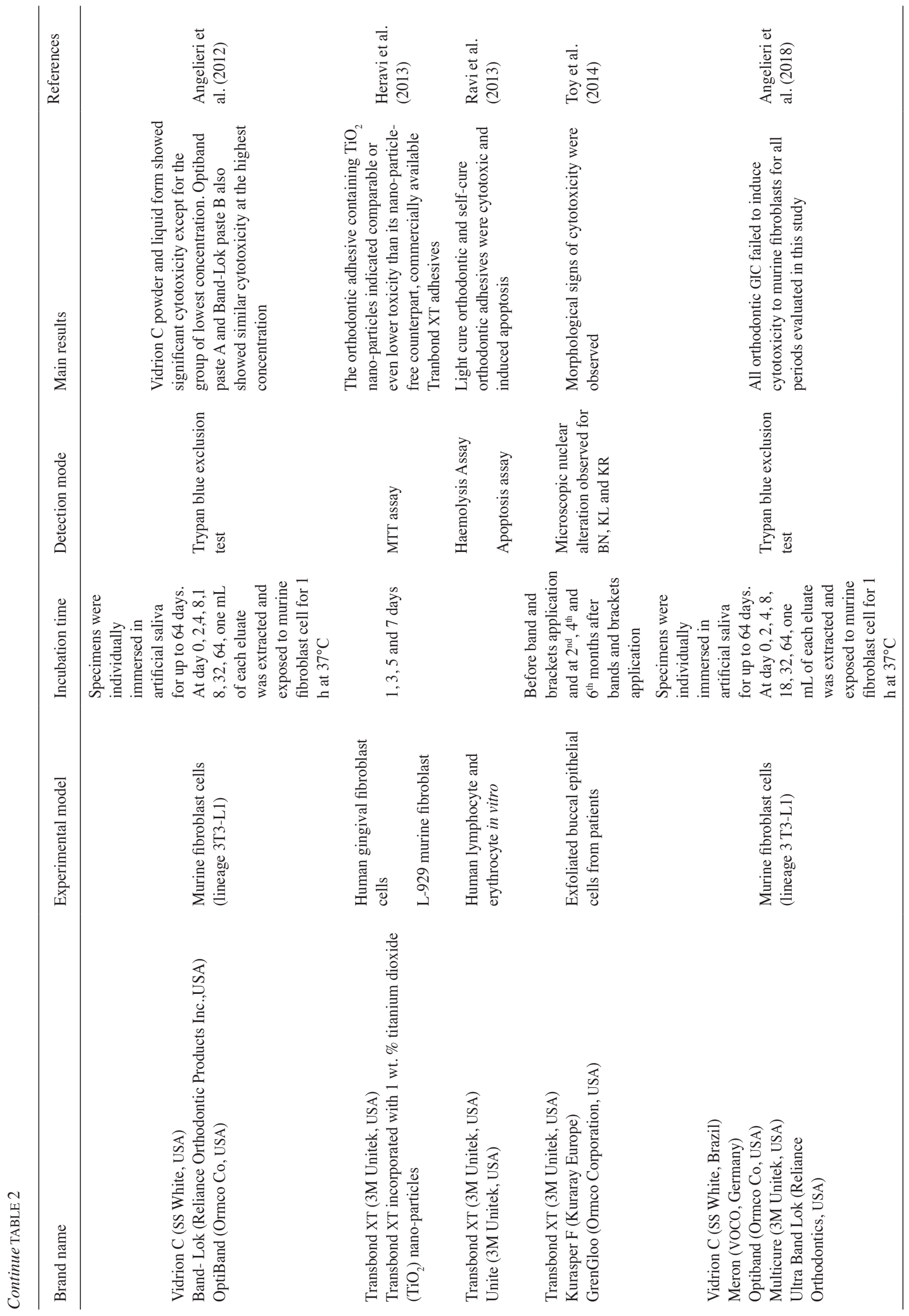


cytotoxicity in their study. Three studies were found where cytotoxicity of Transbond XT was compared with chemical cured orthodontic adhesive where it showed less cytotoxicity than chemical cured adhesives (Jonke et al. 2008; Ravi et al. 2013; Tang et al. 1999). In another study, titanium-dioxide $\left(\mathrm{TiO}_{2}\right)$ nanoparticles were incorporated in commercially available Transbond $\mathrm{XT}\left(\mathrm{TiO}_{2}\right.$ nano-particles free) and aged for 1, 3, 5, 7 and 14 days in DMEM. Then the extracts were obtained and exposed to culture media and were compared for their cytotoxicity using MTT assay (Heravi et al. 2013). The result showed that orthodontic adhesive containing $\mathrm{TiO}_{2}$ nano-particles indicated comparable or even lower toxicity than its nano-particlefree counterpart Transbond XT. In 2002, Huang et al. in their study tested primer component of Transbond XT for cytotoxicity by using MTT assay and found that Transbond XT was cytotoxic.

Angelieri et al. (2012) assessed the cytotoxicity of three types of GIC (Vidiron $\mathrm{C} \circledR$, OptiBand ${ }^{\circledR}$ and bandLok $($ ) ) using Trypan blue exclusion test. Powders or pastes of GIC were prepared in increasing concentrations ranging from 10 to $1000 \mathrm{mg} / \mathrm{mL}$, and liquids were prepared with dilutions from 0.1 to $10 \%$. They were then treated with murine fibroblast cells (lineage 3T3-L1) prior to cytotoxicity assays. Data in this study showed that there is a correlation between the cytotoxicity of GIC component with their concentration. Except for the lowest concentration, all other concentrations of both powder and liquid part of Vidrion C showed a significant level of cytotoxicity. Same cytotoxicity was observed by the paste component of both Band-Lok and OptiBand. The same authors in 2018 investigated the cytotoxicity of five commercially available GICs (Vidrion C, Meron, Optiband, Multicure and Ultra band Lok) in murine fibroblasts using Trypan blue exclusion test (Angelieri et al. 2018). In this study, they showed that no GICs showed cytotoxicity whereas their previous study in 2012 showed cytotoxicity of Vidrion C, Band-Lok and OptiBand (Angelieri et al. 2012). Authors mentioned that the difference in the experimental design could explain the result difference between these two investigations as this study evaluated the effects of eluates taken from orthodontic cements and not the powder, liquid or pastes of these, but the authors suggested that further studies are needed to overcome these issues.

It is important to note that during clinical application of orthodontic bonding, excessive bonding adhesive left around the bracket is under the influence of atmospheric oxygen that compromises its polymerization reaction giving rise to an oxygen-inhibited layer of low molecular weight (Peutzfeldt \& Asmussen 1989). Also, atmospheric oxygen has a high affinity for free radicals and tends to prematurely terminate the chain reaction of the monomers, leaving behind a layer of short chain hydrocarbon on the adhesive surface (Ruyter 1981). Both these leaching components inside the resin bulk and the oxygen inhibiting layer (OIL) may produce cytotoxic effects which compromise the bond strength (Eliades \& Caputo 1989; Rueggeberg \& Margeson 1990).
All these studies suggested the importance of case-bycase safety evaluations of orthodontic bonding adhesives because the composition and the treatments performed on the materials have a role in the resulting cytotoxicity.

\section{CONCLUSION}

Due to the diversity in the composition of the materials and the manufacturing techniques applied to orthodontic materials, along with the variety of treatment lengths and intraoral conditions in orthodontics, safety evaluations of orthodontic materials on a case-by-case are required. Thus, a biocompatibility assessment including cytotoxicity and genotoxicity aspects is mandatory prior to their clinical use. Most of the studies showed potential toxic effects in orthodontic adhesives. These additional studies would allow researchers to draw clear conclusions while also taking the contradictory results available now into account. In relation to both cytotoxicity, again the number of in vivo studies is small in the scientific literature compared to in vitro studies. However, in vivo studies provide valuable information on the effects of orthodontic materials in real clinical exposure scenarios. Therefore, further clinical studies considering larger populations and longer treatment periods are necessary. Moreover, it is advisable to employ several genetic assays and standardized methods to evaluate genotoxicity, both in vitro but mainly in vivo, as these studies are scarce in the literature. To reduce the potential genotoxic and cytotoxic effects, various preventive measures can be followed. The clinician should use only as much material as necessary, and care should be taken to remove excess polymerized adhesives, particularly in areas where the adhesives may come in intimate contact with the subgingival and interproximal tissues. Excess activator material has to be removed thoroughly by washing the tooth with a water spray once the adhesive has set.

\section{ACKNOWLEDGEMENTS}

This work was supported by Universiti Sains Malaysia through short term grant (304.PPSG.61313211).

\section{REFERENCES}

Ahrari, F., Tavakkol Afshari, J., Poosti, M. \& Brook, A. 2010 Cytotoxicity of orthodontic bonding adhesive resins on human oral fibroblasts. The European Journal of Orthodontics 32(6): 688-692.

Aldridge, W. 1993. The biochemical principles of toxicology. Experimental Toxicology 5: 56-78.

Angelieri, F., da Silva, Y.S. \& Ribeiro, D.A. 2018. Genotoxicity and cytotoxicity induced by eluates from orthodontic glass ionomer cements in vitro. The Saudi Dental Journal 30(1): $38-42$

Angelieri, F., Joias, R.P., Bresciani, E., Noguti, J. \& Ribeiro, D.A. 2012. Orthodontic cements induce genotoxicity and cytotoxicity in mammalian cells in vitro. Dental Research Journal 9(4): 393-398. 
Angelieri, F., Carlin, V., Martins, R.A. \& Ribeiro, D.A. 2011a. Biomonitoring of mutagenicity and cytotoxicity in patients undergoing fixed orthodontic therapy. American Journal of Orthodontics and Dentofacial Orthopedics 139(4): e399-e404.

Angelieri, F., Marcondes, J.P.C., de Almeida, D.C., Salvadori, D.M. \& Ribeiro, D.A. 2011b. Genotoxicity of corrosion eluates obtained from orthodontic brackets in vitro. American Journal of Orthodontics and Dentofacial Orthopedics 139(4): 504-509.

Angiero, F., Farronato, G., Dessy, E., Magistro, S., Seramondi, R., Farronato, D., Benedicenti, S. \& Tete, S. 2009. Evaluation of the cytotoxic and genotoxic effects of orthodontic bonding adhesives upon human gingival papillae through immunohistochemical expression of p53, p63 and p16. Anticancer Research 29(10): 3983-3987.

Assad, M., Lombardi, S., Berneche, S., Desrosiers, E., Yahia, L. \& Rivard, C.H. 1994. Assays of cytotoxicity of the nickeltitanium shape memory alloy. Proceedings from Annales de chirurgie.

Bishara, S.E., Von Wald, L. \& Zamtua, J. 1998. Effects of different types of light guides on shear bond strength. American Journal of Orthodontics and Dentofacial Orthopedics 114(4): 447-451.

Brendler-Schwaab, S., Hartmann, A., Pfuhler, S. \& Speit, G. 2005. The in vivo comet assay: Use and status in genotoxicity testing. Mutagenesis 20(4): 245-254.

Bull, S., Fletcher, K., Boobis, A. \& Battershill, J. 2006. Evidence for genotoxicity of pesticides in pesticide applicators: A review. Mutagenesis 21(2): 93-103.

Cross, N.G., Taylor, R.F. \& Nunez, L.J. 1983. 'Single-step' orthodontic bonding systems: Possible mutagenic potential. American Journal of Orthodontics and Dentofacial Orthopedics 84(4): 344-350.

Eliades, G. \& Caputo, A. 1989. The strength of layering technique in visible light-cured composites. Journal of Prosthetic Dentistry 61(1): 31-38.

Falconi, M., Teti, G.,Zago, M., Pelotti, S., Breschi, L. \& Mazzotti, G. 2007. Effects of HEMA on type I collagen protein in human gingival fibroblasts. Cell Biology and Toxicology 23(5): 313-322.

Forss, H. 1993. Release of fluoride and other elements from light-cured glass lonomers in neutral and acidic conditions. Journal of Dental Research 72(8): 1257-1262.

Fredericks, H.E. 1981. Mutagenic potential of orthodontic bonding materials. American Journal of Orthodontics and Dentofacial Orthopedics 80(3): 316-324.

Hanks, C., Strawn, S., Watahai, J. \& Craig, R. 1991. Cytotoxic effects of resin components on cultured mammalian fibroblasts. Journal of Dental Research 70(11): 1450-1455.

Hanks, C., Wataha, J., Parsell, R. \& Strawn, S. 1992. Delineation of cytotoxic concentrations of two dentin bonding agents in vitro. Journal of Endodontics 18(12): 589-596.

Heravi, F., Ramezani, M., Poosti, M., Hosseini, M., Shajiei, A. \& Ahrari, F. 2013. In vitro cytotoxicity assessment of an orthodontic composite containing titanium-dioxide nanoparticles. Journal of Dental Research, Dental Clinics, Dental Prospects 7(4): 192-198.

Huang, T.H., Tsai, C.Y., Chen, S.L. \& Kao, C.T. 2002. An evaluation of the cytotoxic effects of orthodontic bonding adhesives upon a primary human oral gingival fibroblast culture and a permanent, human oral cancer-cell line. Journal of Biomedical Materials Research 63(6): 814-821.
Jagdish, N., Padmanabhan, S., Chitharanjan, A.B., Revathi, J., Palani, G., Sambasivam, M., Sheriff, K. \& Saravanamurali, K. 2009. Cytotoxicity and degree of conversion of orthodontic adhesives. The Angle Orthodontist 79(6): 1133-1138.

Jonke, E., Franz, A., Freudenthaler, J., König, F., Bantleon, H.P. $\&$ Schedle,A. 2008. Cytotoxicity and shear bond strength of four orthodontic adhesive systems. The European Journal of Orthodontics 30(5): 495-502.

Malkoc, S., Corekci, B., Ulker, H.E., Yalçın, M. \& Şengün, A. 2010. Cytotoxic effects of orthodontic composites. The Angle Orthodontist 80(4): 759-764.

McKelvey-Martin, V., Green, M., Schmezer, P., Pool-Zobel, B., De Meo, M. \& Collins, A. 1993. The single cell gel electrophoresis assay (comet assay): A European review. Mutation Research/Fundamental and Molecular Mechanisms of Mutagenesis 288(1): 47-63.

Müller, B., Eisenträger, A., Jahnen-Dechent, W., Dott, W. \& Hollender, J. 2003. Effect of sample preparation on the in vitro genotoxicity of a light curable glass ionomer cement. Biomaterials 24(4): 611-617.

Murray, P.E., García Godoy, C. \& García Godoy, F. 2007. How is the biocompatibilty of dental biomaterials evaluated? Medicina Oral, Patología Oral y Cirugía Bucal (Internet) 12(3): 258-266.

Ozturk, F., Toy, E., Hatunoglu, E., Bozkurt, B.S. \& Hakki, S.S. 2014. Real-time cell analysis of cytotoxicity of orthodontic cements on gingival fibroblasts. Journal of Orthodontic Research 2: 32-37.

Peutzfeldt, A. \& Asmussen, E. 1989. Oxygen-inhibited surface layers on microfill pontic. Acta Odontologica Scandinavica 47(1): 31-33

Ravi, M., Vijay, R., Kumari, S. \& Panchasara, C. 2013. Cytotoxic and genotoxic effects of orthodontic adhesives on human lymphocyte-An in vitro study. Medicine Sciences 2(4): 820.

Ribeiro, D., Marques, M.E.A. \& Salvadori, D.M.F. 2006a. Biocompatibility of glass-ionomer cements using mouse lymphoma cells in vitro. Journal of Oral Rehabilitation 33(12): 912-917.

Ribeiro, D.A., Marques, M.E.A. \& Salvadori, D.M.F. 2006b. Genotoxicity and cytotoxicity of glass ionomer cements on Chinese hamster ovary (CHO) cells. Journal of Materials Science: Materials in Medicine 17(6): 495-500.

Rix, D., Foley, T.F. \& Mamandras, A. 2001 . Comparison of bond strength of three adhesives: Composite resin, hybrid GIC, and glass-filled GIC. American Journal of Orthodontics and Dentofacial Orthopedics 119(1): 36-42.

Rueggeberg, F. \& Margeson, D. 1990. The effect of oxygen inhibition on an unfilled/filled composite system. Journal of Dental Research 69(10): 1652-1658.

Rueggeberg, F.A., Maher, F.T. \& Kelly, M.T. 1992. Thermal properties of a methyl methacrylate-based orthodontic bonding adhesive. American Journal of Orthodontics and Dentofacial Orthopedics 101(4): 342-349.

Ruyter,I.E. 1981. Unpolymerized surface layers on sealants. Acta Odontologica Scandinavica 39(1): 27-32.

Saito, K., Hayakawa, T., Kawabata, R., Meguro, D. \& Kasai, K. 2009. In vitro antibacterial and cytotoxicity assessments of an orthodontic bonding agent containing benzalkonium chloride. The Angle Orthodontist 79(2): 331-337.

Santos, R.L.d., Pithon, M.M., Fernandes, A.B.N., Cabral, M.G. \& Ruellas, A.C.d.O. 2010. Biocompatibility of orthodontic adhesives in rat subcutaneous tissue. Journal of Applied Oral Science 18(5): 503-508. 
Schweikl, H., Schmalz, G. \& Spruss, T. 2001. The induction of micronuclei in vitro by unpolymerized resin monomers. Journal of Dental Research 80(7): 1615-1620.

Stick, H.F. \& Rosin, M.P. 1983. Quantitating the synergistic effect of smoking and alcohol consumption with the micronucleus test on human buccal mucosa cells. International Journal of Cancer 31(3): 305-308.

Tang, A.T., Liu, Y., Björkman, L. \& Ekstrand, J. 1999. In vitro cytotoxicity of orthodontic bonding resins on human oral fibroblasts. American Journal of Orthodontics and Dentofacial Orthopedics 116(2): 132-138.

Terhune, W.F., Sydiskis, R.J. \& Davidson, W.M. 1983. In vitro cytotoxicity of orthodontic bonding materials. American Journal of Orthodontics and Dentofacial Orthopedics 83(6): 501-506.

Tice, R.R., Agurell, E., Anderson, D., Burlinson, B., Hartmann, A., Kobayashi, H., Miyamae, Y., Rojas, E., Ryu, J.C. \& Sasaki, Y. 2000. Single cell gel/comet assay: Guidelines for in vitro and in vivo genetic toxicology testing. Environmental and Molecular Mutagenesis 35(3): 206-221.

Toy, E., Yuksel, S., Ozturk, F., Karatas, O.H. \& Yalcin, M. 2014. Evaluation of the genotoxicity and cytotoxicity in the buccal epithelial cells of patients undergoing orthodontic treatment with three light-cured bonding composites by using micronucleus testing. The Korean Journal of Orthodontics 44(3): 128-135.

Vande Vannet, B.M.R.A. \& Hanssens, J.L. 2007 . Cytotoxicity of two bonding adhesives assessed by three-dimensional cell culture. The Angle Orthodontist 77(4): 716-722.
Wright, A.B.,Lee, R.T., Lynch, E. \& Young, K.A. 1996. Clinical and microbiologic evaluation of a resin modified glass ionomer cement for orthodontic bonding. American Journal of Orthodontics and Dentofacial Orthopedics 110(5): 469475.

Riaz Mohammad Adham, Norma Ab Rahman* \& Thirumulu Ponnuraj Kannan

School of Dental Sciences

Universiti Sains Malaysia

16150 Kota Bharu, Kelantan Darul Naim

Malaysia

Thirumulu Ponnuraj Kannan

Human Genome Centre

School of Medical Sciences

Universiti Sains Malaysia

16150 Kota Bharu, Kelantan Darul Naim

Malaysia

*Corresponding author; email: drnorma@usm.my

Received: 26 October 2018

Accepted: 8 May 2019 